\title{
To What Scope Does International Law Impact the Way States Behave and Interact with Each Other and Why are International Institutions-Watchdogs of International Law- So Fundamental to the Liberals?
}

\author{
Pa Modou Drammeh \\ Affiliation: Ege University, Turkey
}

\begin{abstract}
"The collapse of good conscience and the absence of accountability and public scrutiny have led to crimes against humanity and violations of international law." Nelson Mandela. It goes without saying that International law has a great impact on the way states behave and interact with each other and so it does ascertain whether there is any threat to world peace or not, a breach of that peace, or any act of aggression that may undermine and sabotage international order. Ludwig Quidde was prompt to submit that: "every success in limiting armaments is a sign that the will to achieve mutual understanding exists, and every such success thus supports the fight for international law and order." And he added that, the security of which we speak is to be attained by the development of international law through an international organization based on the principles of law and justice. It is noncontroversial that international law plays a key role in determining and regulating the relations of states in the global community. This paper attempts to describe how the main actors in international relations- the states- act and interact in our global environment within the parameters of international laws. It goes to show the scope in which the relations among states are determined by international law. While the foreign policy of a state arguably remains key to the conduct of relations with other states, international law serves as the Do's and Don'ts that govern the extent in which states behave and interact with each other. Meanwhile, international institutions are a principal focus of international relations scholars, to be precise, the liberals, commonly called idealist by E.H Carr. The writer also seeks to examine and scrutinize the prominences of International institutions- watchdogs of international laws- to the liberals and the ways in which it has been theorized. It develops a definition from the liberal perspective and attempt to provide a conceptual framework of liberal institutionalism. It is hoped that the concept of war, the spirit of cooperation and democracy, prospects for peace, international order and justice will be analyzed through liberal lenses.
\end{abstract}

Keywords: International, law, liberals, institutionalism, security, organization, peace, cooperation

DOI: $10.7176 / \mathrm{IAGS} / 73-01$

Publication date:June $30^{\text {th }} 2019$

The scope in which international law influence the way states behave and interact

In today's world, states are the most crucial actors in international relations. The writer safely assume that it is important to connect the origin of state to international law in order to give this paper a seemly introduction. Machiavelli an Italian political thinker was the first to use the word State in his classic work "The Prince" published in 1523 A.D. One of the greatest political thinkers of all times, Aristotle, had this to say about state: "a union of families and villages having for its end a perfect and self-sufficing life by which we mean a happy and honorable life". (W. D., Aristotle, London, Methuen, 1937). Aristotle's definition could be linked back to the 1930s before the rise of modern state. Modern state started in Western Europe and ultimately encompasses the globe. 1948 can be seen as the birthday of nation-state, the year of the Treaty of Westphalia. The Montevideo Convention which defined the rights and duties of States was signed at Montevideo in Uruguay, on December 26, 1933. This convention obviously gave the state a standard definition under international law. Article 1 of this international agreement declares: "The state as a person of international law should possess the following qualification: a permanent population, a defined territory, government and the capacity to enter into relations with other states." 2 ( J. Klabbers, 2016). This convention has manifested the means in which a state can enter into relations with other states according to international law. Therefore, international laws do not only influence to a great extent how states behave and interact with each other, but also shape their co-existence.

Many legal minds and practitioners and international relations scholars strongly believe that international law matters due to the fact that it effects the behavior of states. All states in the global community, be it small powers or great powers, are compelled to obey international laws in their relations with other states and should justify their actions and behavior according to the principles of legal rules and regulations and accepted norms. The very extent

\footnotetext{
${ }^{1}$ W. D., Aristotle, London, Methuen, 1937, p. 247

${ }^{2}$ Montevideo Convention on Rights and Duties of States. (2016). In J. Klabbers (Ed.), International Law Documents (pp. 2-4). Cambridge: Cambridge University Press.
} 
to which states comply with international law determines how they interact and behave with each other. The United Nations Charter formally became the global strucutre for which norms of sovereignty and non-intervention were incorporated. Now, as a result of modern technology, communication, transport, and more, the evolving process of Globalisation, "The internationalization of the world", has provided an opportunity for international law and accepted norms and principles to reach every corner of the globe. ${ }^{1}$ ( Heath Pickering. H, 2013) Going by the UN charter ( 1949) -the Declaration on Rights and Duties of States- it is the sole right of every state to enjoy juridical equality under the parameters of international law. States have the sole right to define their own political position and exercise permanent sovereignty inside the boundaries of their territorial jurisdiction ${ }^{2}$ (Schwebel, 1963).

Initially, international law was more about issues relating to the territorial disputes, jurisdiction and intervention. But now, with the passage of time, international law has expanded and it includes human rights, labour laws, economics, communication etc. These laws govern what states are allowed to do and not to do especially in their relations with other states. For example, it is against international law for any state to trespass into the territorial boundary of other states unless and until it is an international agreement. "International law, then, consists of norms of which the subjects (persons obligated) are states, and of which the objects (things regulated) are relations between states."3 (Patterson, Jurisprudence, 1953) The way in which the international law is interpreted plays a vital role in shaping the behavior of the state. For example, the case of Kosovo in March 1999. "Member states of NATO decided to take action against the former Republic of Yugoslavia, clearly illustrates the point. Here, the US and France disagreed over the interpretation of international legal rules" $(\mathrm{H}$ Lauterpacht, 2010) "The US sought to go after what they believed as strategic military targets, while France believed it to be inconsistent with NATO's mission. The disagreement over the interpretation of international law as Wheeler puts it, demonstrates that agreement on the relevant legal rules is no guarantee that actors will agree on their application in particular cases"5 (HH Koh, 1997) This diagreement cited can even effect the relations among the states involved.

International laws and norms undoubtedly shape the way states interact with each other. Barnett (2011) defined norms as: "being principles of the accepted behaviour for actors with a given identity."6 (Barnett, M. (2011) International law or norm has a great power in determining the behaviour of actors. States are also concerned about their outlook on the international arena so therefore, they are careful in their interaction and behaviour with other states. Barnett provides a glaring example of how states try to maintain civilization in their conduct and behaviour. He states: "it is a norm within international relations that nation states stay away from resolving any misunderstanding which they may have in the course of violence, not to say that violence might not effectively provide some form of results, but due to the reason that violence violates how civilised nations expected to behave towards one another."7 ( Barnett, M. 2011) It can be argued that International laws dictate how states involve with other states. This would have a great impact in shaping any state behaviour.

In the book authored by Louis Henkin, How Nations Behave, he claims that: "Almost all nations observe almost all principles of international law and almost all of their obligations almost all of the time." ( H. Louis, 1997) Let me bring to you the practical aspect of international law in relations to state-to-state behaviour. For example, when a state is trading with another state in material goods both states have to make sure no international law governing international trade is violated and many other issues could be cited as examples. There are reference to international law as states attempt to justify their foreign policy towards various issues. This goes to justify their relations and interaction with each other. Isreali case in the 1960s can also be taken as an example. "In 1960s Isreali agents kidnapped Adolf Eichmann from Argentina territory. This violation of international law sparked protest from all quarters. Isreali, having accomplished its goal apologized to Argentina, which had no great desire to draw attention to its colony of former Nazis and accepted the apology." ( Hannah Arendt, 1994) Kidnapping is wrong and illegal in international law and such an act can possibly sour the relations between states. The writer safely assume that International law can strongly shape the relations among states.

\section{The importance of International Institutions to the Liberals}

Historically, the calamitous nature of the First World War or the Great War dramatically switched the minds of liberal thinking towards an acknowledgment that peace is not a natural condition or phenomenon but is one which

\footnotetext{
${ }^{1}$ Heath Pickering, Why Do States Obey International Laws, 2013, University of Melbourne.

${ }^{2}$ Schwebel, S. M. (1963) The Story of the U.N.'s Declaration on Permanent Sovereignty over Natural Resources. 49 American Bar Association Journal.

3 Patterson, Jurisprudence 174 (1953). The definition from Hyde appears in

1 Hyde, International law 1 (2d ed. 1945).

${ }^{4} \mathrm{H}$ Lauterpacht, The Development of International Law by the International Court (1st, Cambridge University Press, Cambridge 2010)

${ }^{5}$ HH Koh, 'Why do Nations Obey International Law?' [1997]

${ }^{6}$ Barnett, M. (2011), Social Constructivism in Baylis, J., Smith, S. and Owens, P. The Globalization of World Politics: Oxford University Press

${ }^{7}$ Barnett, M. (2011), Social Constructivism in Baylis, J., Smith, S. and Owens, P. The Globalization of World Politics: Oxford University Press

${ }^{8}$ H Louis, How Nations Behave, Columbia University Press, New York 1979

${ }^{9}$ Hannah Arendt, Eichmann in Jerusalem 239-240, 1994
} 
must be constructed and sustained. The most well-known liberal advocate for the establishment of international institution for the sole management and maintenance of world peace and order was, the United States erstwhile president, Woodrow Wilson. According to Wilson, ultimate peace can only be secured with the establishment of international institutions or organizations that will serve as a mechanism and tool for the regulation of international anarchy. Kenneth Walt a neorealist and political scientist in his famous book Theories of International Politics (1979) defined anarchy as the lack of world leader or any supreme authority in the international arena. ${ }^{1}$ (Theories of International Politics, 1979) Woodrow Wilson proclaimed: "A general association of nations must be formed under the specific covenants for the purpose of affording mutual guarantees of political independence and territorial"2 (Wilson Fourteen Point Speech, 1918- www.kjodle.com). His statement was centered on peace and his liberal mind laid the foundation. Wilson further professed that there should not be any private or secret international action or ruling so that diplomacy shall be conducted in an open and honest manner for the sake of the effective balance of power in international politics. "Just as peace had to be enforced in domestic society, the international domain had to have a system of regulation for coping with disputes and an international force which could be mobilized if non-violent conflict resolution failed."3 (Tim Dunne. (1979: an introduction to international relations, Oxford University Press). Wilson in his liberal thinking further argued that for an effective and vibrant institution it is necessary to have military power to prevent any form of aggression, and when deem necessary, to use such a military power to enforce its will. This led to the popular concept of collective security. "Collective security may be defined as a plan for maintaining peace through an organization of sovereign states, whose members pledge themselves to defend each other against attack"4 (Encyclopedia of American Foreign Policy). In a nutshell, International institution is so important to the liberals for the maintenance of world peace as highlighted between the lines. After the dust of the First World War settled down in 1918, liberals wanted to use the creation of international institutions as a mechanism for the prevention of another world war. In theory, liberals hold the belief that the chances of war can be prevented through enhancing effective communication and facilitating cooperation among nation states.

Liberal thinkers vehemently believe that international institutions are of utmost importance in cooperating states. During his millennium commencement speech, the former Secretary General of the United said that more than ever before in human history, we share a common destiny and that destiny can also be mastered if we face it together collectively in the interest of world peace. Kofi Annan, a liberal thinker believed that we have a common destiny and we should face it together through cooperation and the United Nations was created to facilitate that process. Liberal vehemently hold the conviction that through the creation of International institutions can only international cooperation be facilitated. Liberal thinkers see international institutions are forums or platforms where nation states can voice their opinions amicably and promote dialogue. Liberals believe in dialogue and the peaceful settlement of disputes. According to the liberals, with cooperation, nations can aid each other's efforts to achieve common goals under without encroaching states' sovereignty or undemocratically intervening in the interval affairs of states. International institutions are tools for liberals to promote discussion and resolve conflicts. International institutions are highly important for maintaining a stable international environment. The neo-liberals believe that states have limited material and intellectual resources, so by cooperating with others can boost their economic sectors because when their economies are interconnected the chances of waging war on one another is very limited. This concepts promotes the idea of international trade and interdependence. Interdependence can be through trade, blending cultures and the likes of it.

The fundamental focus of liberalism on state-state relations formation is centered on İnternational law. Consequently, liberal thinkers or theorists have been expanding their theoretical analysis on international law. The world is growing and states are getting bigger and expanding and so the need for cooperation and the guidance of effective cooperation among states is through the formulation of international laws to guide states' conduct and behavior in the international arena. Now the million dollar-question arises: How can international laws be formulated and guided? According to the liberals, international institutions are necessary to serve as watchdogs for international laws. International laws can be promoted and safeguarded through international institutions. According to the liberals, one of the sub-state actors as a function of structure is globalization. Liberals believe that the negative trends of globalization can be controlled or at least limited through a system of governing laws.

\section{In conclusion}

States are subjected to international laws and norms and not at free will to do whatever they desire. Their behavior and actions must be justified and should be in line with international principles and norms. Few cases and examples have been cited in order to conclude logically. The initiation and implementation of international law have greatly influenced how states behave and act. The fundamental reason that led to the development of

\footnotetext{
${ }^{1}$ Kenneth Walt, Theories of International Politics (1979)

${ }^{2}$ Wilson Fourteen Point Speech, 1918- www.kjodle.com

${ }^{3}$ (Tim Dunne. (1979: an introduction to international relations, Oxford University Press)

${ }^{4}$ Encyclopedia of American Foreign Policy
} 
international law was for the preservation and maintenance of peace. It was needed to regulate the relations of state and foster peaceful settlement of disputes among states. On the other hand, this essay has also analyzed the importance of international institutions to the liberals and advanced arguments on the interpretation and theoretical framework of international institutions through a liberal lens. For liberals, international institutions will always be effective in promoting international peace and order, dialogue and dispute settlement. Liberals strongly hold the view that international institutions regulate state conduct through cooperation. Liberals see institutions as a mechanism that can be used to achieve a more peaceful and progressive world while maintaining the principle of non-state intervention and sovereignty.

\section{References}

Ross, W. D., Aristotle, London, Methuen, 1937.

Montevideo Convention on Rights and Duties of States. (2016). In J. Klabbers (Ed.), International Law Documents (pp. 2-4). Cambridge: Cambridge University Press.

Heath Pickering, Why Do States Obey International Laws, 2013, University of Melbourne.

Schwebel, S. M. (1963) The Story of the U.N.'s Declaration on Permanent Sovereignty over Natural Resources. 49 American Bar Association Journal.

Patterson, Jurisprudence 174 (1953). The definition from Hyde appears in 1 Hyde, International law 1 (2d ed. 1945).

H Lauterpacht, The Development of International Law by the International Court (1st, Cambridge University Press, Cambridge 2010)

HH Koh, 'Why do Nations Obey International Law?' [1997] YLS

Barnett, M. (2011), Social Constructivism in Baylis, J., Smith, S. and Owens, P. The Globalization of World Politics: Oxford University Press

H Louis, How Nations Behave, Columbia University Press, New York 1979

Hannah Arendt, Eichmann in Jerusalem 239-240, 1994

Waltz K. (1979) Theories of International Relations

Tim Dunne. (1979) The globalization of world politics: an introduction to international relations, Oxford University Press

Wilson Fourteen Point Speech (www.kjodle.com)

Encyclopedia of American Foreign Policy.

Jeffrey L. Dunoff \& Mark A. Pollack, eds., International Law and International Relations: The State of the Art

\section{Futher reading:}

Brownlie, I., \& Crawford, J. (2012). Brownlie's principles of public international law. Oxford University Press.

Reisman, W. M. (1990). "Sovereignty and human rights in contemporary international law". American Journal of International Law, 84(4), 866-876.

Barker, J. C. (2000). International law and international relations. A\&C Black. Byers, M. (Ed.). (2001). The role of law in international politics: essays in international relations and international law. Oxford University Press on Demand.

Grewe, W. G. (2013). The epochs of international law. Walter de Gruyter. - Goldsmith, J. L., \& Posner, E. A. (2005). The limits of international law. Oxford University Press.

Reus-Smit, C. (Ed.). (2004). The politics of international law (Vol. 96). Cambridge University Press.

Malanczuk, P. (2002). Akehurst's modern introduction to international law. Routledge

The International Commission on Intervention and State Sovereignty report. 2002.

Bellamy, Alex. 'The Responsibility to Protect—five years on,' Ethics and International Affairs 24, 2010, 143-169 